\title{
The Effect of the Relationship Between Cash Flows From Operating Activities and Earnings per Share in Jordan
}

\author{
Yaser Mohd Ahmed Hamshari ${ }^{1}$ \\ ${ }^{1}$ Accounting Department, College of Administrative and Financial Sciences, Petra University, Amman, Jordan \\ Correspondence: Dr. Yaser Mohd Ahmed Hamshari, Assistant Professor, Accounting Department, College of \\ Administrative and Financial Sciences, Petra University, Amman 11196, Jordan. E-mail: yasermohd2008@gmail.com
}

Received: February 17, 2020

Accepted: April 7, 2020

Online Published: July 7, 2020

doi:10.5430/ijfr.v11n4p289

URL: https://doi.org/10.5430/ijfr.v11n4p289

\begin{abstract}
The study assumes that there is a relationship between the cash flows from the operational activity and the earnings per share. The companies listed on the Amman Stock Exchange have been studied, including the banking sector, the insurance companies sector, and the service sector (education sector). One of the objectives of the study was to know that the administration exploits all available capabilities and achieve quality in profits through activities, operating, financing and investment in a way that achieves a sense of security for the investor and who is waiting for the reward that he invested his money in order to obtain a return that meets what is expected. Therefore, it was necessary to educate users of the data of the importance of understanding and studying the list of cash flows as an analytical tool.

It is assumed that the conclusion of this study is that there is a strong relationship between cash flows from operating activity and earnings per share (earnings per share) with a need to pay attention to operational activity and provide and create economic conditions and laws and legislation that help to strengthen and achieve voluntary power because it reflects the continuity of facilities and companies.
\end{abstract}

Keywords: cash flow, operating activities, earnings per share

\section{The General Framework of Study}

\subsection{Introduction}

One of the important functions of financial analysis is the analysis of the cash flow list and the indicators that can be extracted from it. The cash flow statement is a link between the income and general budget statements. Therefore it can reveal the strengths and weaknesses of the enterprise activity through the important information that it reveals, so some studies that Conducted by (Sunder, 1973) reached the conclusion that investors have shown an interest in cash flows, so the lender in the short term is more concerned with the ability of the facility to achieve cash flows than with interest in profitability to ensure the collection of short-term debt the investor is interested in the facility's ability to achieve cash flows, its importance in determining the share price, as well as management is interested in it to identify the need for external financing and to efficiently plan and manage cash resources (Al-Khalayleh, 2018). As it reflects the main activity of the project and has a recurring nature and receives special attention if the project is able to achieve positive cash flows from what facilitates it to obtain cash from financing activities.

\subsection{The Importance of Study}

The necessity of paying attention to the operational activities as it is the nerve of the establishment and creating laws and legislations to support the facilities in developing operational activities for the benefit of the shareholders, management, owners and the state.

\subsection{Objectives of the Study}

This study aims to:

1- Assists data users and financial analysts to assist investors in guiding and planning towards the best investment choice

2- Encouraging the management to focus on the importance of the operational activity, paying attention to it more, and a clear indication of continuity 
3- There is a clear relationship between earnings per share and cash flows from operating activities.

4- Drawing the attention of the decision-makers to the changes or matters that require special attention to address them.

\subsection{Study Limitations}

1- Lack of previous studies that examined this topic, especially in the use of cash flows as an analytical tool.

2- The sample was taken in the field of banks, insurance companies, and the service field (education sector) for comparison in order to find the effect on the nature of the difference in the operational activity and its relationship with the earnings per share.

\subsection{The Study Problem}

Is there a relationship between earnings per share and the statement of cash flows from operating activities?

\subsection{Study Hypotheses}

The financial statements have been used from the Amman Stock Exchange for service companies (education sector), banks and insurance companies for the period between (2014-2018). Accordingly, the following assumptions will be tested in this study:

H1: There is no statistically significant effect between the earnings per share and the statement of cash flows from operating activities.

H 2: There is a statistically significant effect between the earnings per share and the statement of cash flows from operating activities.

\subsection{Study Variables}

\section{1- Earning per share}

One share of net profit from continuing activity after interest and tax

Earnings per share $=$ net income minus the preference share of profits divided by the number of ordinary shares issued and traded by the company

In the event that the number of shares changes during the year, whether increase or decrease, the weighted average number of shares is used during the year to calculate the earnings per share (IAS 33, International Accounting Standards Book D 0 Abunsar and 0 Hamidat - 2020)

2-Cash flows from operating activities

Are the main activities to generate revenue in the facility and other activities that are not considered investment and financing activities and operating cash flows are presented either directly or indirectly (International Accounting Standard No. 7 book of international accounting standards Abunasar and 0 Hamidat - 2020)

\section{Review of Related Literatures}

The study (Abu Al-Rab, 2019) indicated that there is a direct relationship between the operating cash flows and the return on the stock, and that there are extraordinary activities that affect the earnings per share positively, as the study recommended that investors and users should be urged to focus on data related to cash flows, especially operational cash flows to credit facilities In the banking sector because of its impact on determining the earnings per share and is considered one of the indicators of important financial performance, As for the study (Jamal and Dabbash, 2015), the study recommended the necessity of paying attention to the cash flow statement and that there is a positive indicative statistically for the cash flow list to take decisions to distribute profits in commercial banks in the province of Jijel Algeria and that the cash flow list helps investors in knowing and analyzing the extent of The ability of institutions to generate positive cash flows to achieve the return that meets the ambition and need of the investor, while the study (Alwan, 2015) It indicated that the cash flow metrics are an important method of analysis through the available cash to govern liquidity and forecast profitability, and the rate of return on investment is a positive measure of profitability by the variable of the cash flow measure for each of the operational, financing and investment activities, and a study (Al-Amoudi, 2011) That there is a direct relationship between the percentage change in the market value of the stock and cash flows, and that is evidence of the administration's success in managing its cash flows that led to an increase in profits from what led to an increase in the return on the stock and an improvement in profitability. Investing her money, study focused (Dergham, 2008) on the need to pay attention to the list of cash flows and to educate users of financial data of the need to understand and analyze them as being information free from misleading. The study also demonstrated that there is a direct relationship between the earnings per share of statistical significance of the earnings per share and operational cash flows. 


\subsection{Theoretical Framework}

Cash flow analysis: It passed in a long time period during which it evolved in terms of form and content and at each stage of this development the list of flows was commensurate with the needs of businessmen (recent trends in financial and credit analysis (Matar, 2010)

The importance of the statement of cash flows:

1- Providing information that does not appear in any of the income statement and the general budget, meaning that it is a link between these two lists, noting that it is prepared on a cash basis, not a merit.

2- It is considered more appropriate to determine the weaknesses and strengths of the enterprise's activity and the adequacy of the cash flows.

3- Show explanations and explanations about the change in cash, i.e. provide quality or quality of profits.

In accordance with International Accounting Standard No. (7), the statement of cash flows has been classified into three sections:

1- The list of flows from operating activities: It includes the monetary effects of normal operations from buying and selling, collecting its debts and paying its obligations from customers and suppliers.

2- List of flows from investment activities: It includes the purchase and sale of non-current assets and investments from other companies.

3- The list of flows from financing activities: It includes obtaining money from owners and lenders through the issuance of shares, bonds, dividends, or the purchase of treasury shares.

This division helps us know where the cash came from (the sources) and what the use of this cash (uses), the form was of cash flows from the book (Alqam, 2018):

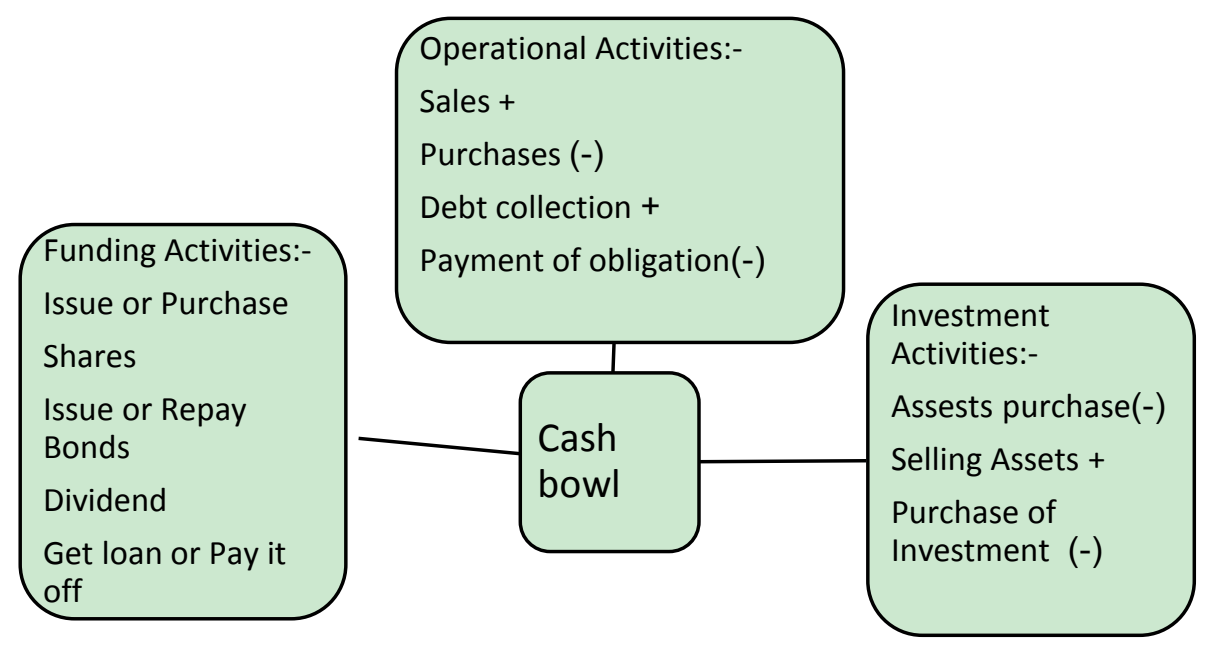

Cash flow statement presentation methods:

There are two methods according to the International Accounting Standard No. (7) to display the list of cash flows, which are the direct method and the indirect method, where the difference between the two methods is in the method of calculating and displaying operational cash flows. And Hamidat, 2019)

Net cash flows from operating activity in the direct way.

\begin{tabular}{lc}
\hline Net cash flows from operating activities (direct method) & \\
\hline Amounts collected from clients & + \\
\hline Interest income and dividends received & + \\
\hline Payments to suppliers & $(-)$ \\
\hline
\end{tabular}




\begin{tabular}{lc}
\hline Total cash operating expenses & $(-)$ \\
\hline Interest expense paid during the period & $(-)$ \\
\hline Net cash flows from operations & $\times \times \times \times \times$ \\
\hline
\end{tabular}

Net cash flows from operating activity in an indirect manner:

\begin{tabular}{lc}
\hline Net profit (income statement) before interest and taxes & $\times \times \times \times$ \\
\hline Depreciation expense & + \\
\hline Amortization expense & + \\
\hline Selling losses and impairment in the value of non-current assets & + \\
\hline Gains from sale of non-current assets & $(-)$ \\
\hline Decrease in current assets & + \\
\hline Increase in current assets & $(-)$ \\
\hline Decrease in current liabilities & $(-)$ \\
\hline Increase in current liabilities & + \\
\hline Cash paid as interest expense & $(-)$ \\
\hline Cash paid as income taxes & $(-)$ \\
\hline Net cash flows from operating activities & $\times \times \times \times$
\end{tabular}

The statement of cash flows, whether prepared in any way, determines the monetary results for each activity that the entity has undertaken during the period being analyzed, while determining the impact of these results.

Earnings per share (EPS):

The return on the stock is considered one of the most used performance indicators to measure the efficiency of the financial performance of companies and measures the amount of profits that pertain to each of the company's shares at the end of the financial period:

Net income - (dividends paid to preference shareholders) / average number of ordinary shares.

Accounting standards stipulate the necessity of disclosing them at the core of the income statement. In the event that the number of ordinary shares changes during the six, whether by increasing or decreasing, the weighted average number of shares is used during the year to calculate the earnings per share and the earnings per share is calculated through the following formula:

Net income - (dividends distributed to Preferred Shareholders) / weighted average common issued and traded shares.

As for the reasons that result in a change in the number of ordinary shares, either the company increases its capital, buy treasury shares, split the stock, or distributes bonus shares, or (transfer the company of preferred shares or bonds) that are convertible into ordinary shares, and there is reduced earnings per share when the head is Money is a compound, especially if there is (convertible shares or bonds) transferable for ordinary shares, stock options, stock rights, or contractual rights to buy shares or shares issued to employees as end of service compensation. The International Accounting Standard (33) stipulates the need to disclose basic earnings per share and reduced earnings per share solidify the income statement and in the company consolidated statements 0 books (Analyzing financial statements for decision-making purposes and evaluating performance (Alqam, 2018).

\section{Research Methodology}

Where descriptive analysis was used by studying some of the companies listed on the Amman Stock Exchange for the period between (2014 - 2018), several sectors were taken, including five banks, five insurance companies and five service sector companies (education sector), and the study was done in this way to see the extent of the difference In the activity and the extent of the impact of laws, legislations and economic conditions on the operational activity and cash flows in the sectors of the study sample. 
Earnings per share for banks

\begin{tabular}{lcccc}
\hline Bank name & Arithmetic mean & standard deviation & $\begin{array}{l}\text { Coefficient of } \\
\text { variation }\end{array}$ & $\begin{array}{l}\text { Correlation } \\
\text { coefficient } \\
\text { between net cash } \\
\text { flow } \\
\text { and earnings } \\
\text { per share }\end{array}$ \\
\hline Jordan Kuwait Bank & 0,345 & 0,071 & 0,207 & 0,631 \\
\hline The Housing Bank & 0,413 & 0,093 & 0,226 & 0,791 \\
\hline $\begin{array}{l}\text { Arab Banking } \\
\text { corporation (ABC) }\end{array}$ & 0,12 & 0,022 & 0,180 & $0,083-$ \\
\hline Cairo Amman Bank & 0,198 & 0,043 & 0,216 & 0,762 \\
\hline Bank of Jordan & 0,228 & 0,024 & 0,104 & 0,295 \\
\hline
\end{tabular}

Looking at the above table, we find that the Housing Bank has the highest value for the arithmetic mean and the standard deviation of the earnings per share by 0.413 and 0.093 respectively, while the lowest value for the arithmetic mean and the standard deviation of one share earnings from the Arab Banking Corporation's share was 0.12 and 0.022 on Straight. Whereas, the highest value of the difference coefficient of the return per share was for the housing bank, which amounted to 0.226, while the lowest value for the Bank of Jordan was by 0.104. As for the correlation coefficient between cash flow and earnings per share, all values were positive except for ABC Bank where the correlation coefficient was negative, and this indicates a weak negative relationship. The highest value of the positive correlation coefficient was for the Housing Bank, which amounted to 0.791, and the lowest value for the Bank of Jordan was 0.295

Earnings per share for insurance companies

\begin{tabular}{|c|c|c|c|c|}
\hline $\begin{array}{l}\text { The Company's } \\
\text { name }\end{array}$ & Arithmetic mean & standard deviation & $\begin{array}{l}\text { Coefficient of } \\
\text { variation }\end{array}$ & $\begin{array}{l}\text { Correlation } \\
\text { coefficient } \\
\text { between net cash } \\
\text { flow and earnings } \\
\text { per share }\end{array}$ \\
\hline $\begin{array}{l}\text { Middle East } \\
\text { Insurance }\end{array}$ & 0,115 & 0,073 & 0,637 & 0,032 \\
\hline $\begin{array}{l}\text { Al-Nisr Al-rabi } \\
\text { Insurance }\end{array}$ & 0,238 & 0,026 & 0,111 & 0,932 \\
\hline $\begin{array}{l}\text { Jordanian } \\
\text { Insurance }\end{array}$ & 0,01 & 0,026 & 2,582 & $0,772-$ \\
\hline Arab Insurance & 0,048 & 0,029 & 0,639 & $0,261-$ \\
\hline Delta Insurance & 0,038 & 0,057 & 1,530 & $0,141-$ \\
\hline
\end{tabular}

Looking at the above table, we find that Al-Nisr Al-Arabi Insurance Company has the highest value of the arithmetic mean of one share earnings, which amounted to 0.238 , while the lowest value of the arithmetic value of one share of the share of the Jordanian insurance company was 0.01 . While the highest value for the standard deviation of the return per share was for the Middle East Insurance Company at 0.073, while the lowest value was for the Al-Nisr Al-rabi Insurance Company and Jordan Insurance Company by 0.026. The highest value of the difference coefficient of the return per share was from the share of the Jordanian Insurance Company, which amounted to 2.582, while the lowest value was for the Al-Nisr Al-rabi Insurance Company by 0.111. As for the correlation coefficient between cash flow 
and earnings per share, some values were negative and the other positive, as it was a negative correlation for both the Jordan Insurance Company and Arab Insurance and Delta Insurance, and the largest value of the negative correlation was from the share of the Jordan Insurance Company with a value of 0.772 - while my company achieved Middle East Insurance and Al-Nisr Al-Arabi Insurance have positive values for the correlation coefficient, and the highest share of the Al-Nisr Al-rabi Insurance Company was 0.932 , which indicates a very strong positive correlation between the earnings per share and cash flow.

Earnings per share for education companies

\begin{tabular}{|c|c|c|c|c|}
\hline $\begin{array}{l}\text { The Company's } \\
\text { name }\end{array}$ & Arithmetic mean & standard deviation & $\begin{array}{l}\text { Coefficient of } \\
\text { variation }\end{array}$ & $\begin{array}{l}\text { Correlation } \\
\text { coefficient } \\
\text { between net cash } \\
\text { flow and earnings } \\
\text { per share }\end{array}$ \\
\hline $\begin{array}{l}\text { Zarqa Education } \\
\text { and Investment }\end{array}$ & 0,128 & 0,072 & 0,563 & 0,920 \\
\hline $\begin{array}{l}\text { Arab International } \\
\text { for Education and } \\
\text { Investment }\end{array}$ & 0,22 & 0,06 & 0,273 & $0,964-$ \\
\hline Union schools & 0,1 & 0,024 & 0,245 & $0,304-$ \\
\hline $\begin{array}{l}\text { Al Isra for } \\
\text { Education and } \\
\text { Investment }\end{array}$ & 0,288 & 0,046 & 0,162 & 0,240 \\
\hline Petra education & 0,43 & 0,027 & 0,063 & 0,008 \\
\hline
\end{tabular}

Looking at the above table, we find that the Petra Education Company has the highest value of the arithmetic mean of one share earnings, which amounted to 0.43 , while the lowest value of the arithmetic average of per share was from the share of Union Schools by 0.1. Whereas, the highest value for the standard deviation of the earnings per share was for Zarqa Education and Investment Company at 0.072, while the lowest value was for Union Schools by 0.024. The highest value of the difference coefficient of each share was attributed to Al-Zarqa Education and Investment Company at 0.563 , while the lowest value for Petra Education was 0.063 . As for the correlation coefficient between cash flow and earnings per share, some values were negative and the other positive, as it was a negative correlation factor for both Arab International for Education and Union Schools, and the largest negative correlation was for the Arab International Company for Education and Investment with a value of 0.964 - this indicates A very strong negative correlation was linked between earnings per share and cash flow. While Zarqa companies for education and investment and Al Isra for education and investment and Petra for education achieved positive values for the correlation coefficient, and the highest value was attributed to the share of Zarqa for Education and Investment Company, which amounted to 0.920 , and this indicates a very strong correlation between the earnings per share and cash flow.

\section{Results \& Conclusion}

1- There is a clear relationship between the cash flows from operating activities and earnings per share (earnings per share). The correlation coefficient was positive in the banking sector, the Housing Bank and in the insurance sector, Al-Nisr Al-Arabi Company. As for the education sector, it was the Zarqa Education and Investment Company.

2- As for the highest arithmetic mean and the standard deviation among all sectors, the Housing Bank has the highest difference coefficient. The Jordanian Insurance Company was in what was the Al-Nisr Al-rabi Insurance Company the highest correlation coefficient. 


\section{Recommendations}

1- The necessity of educating and guiding the users of the financial statements of the importance of the cash flow list and emphasizing its importance as a tool of analytical tools, especially investors.

2- The necessity of conducting several studies to find out the factors that help increase the voluntary power of enterprises and companies to take care of operational, financing and investment activity and to increase positive cash flows through creating laws, legislations, economic conditions and a work and competitive environment to attract and draw the attention of investors and the presence of returns that meet its ambitions

\section{References}

Abu Al-Rub, L. (2019). Financial Ratios Extracted from Operating Cash Flows to Earnings Per Share. Master Thesis, College of Business - Accounting Specialization, Middle East University, Amman - Jordan. Retrieved from http://meu.edu.jo/libraryTheses/5ca89eecddde1_1.pdf

Abu Nassar, Jum`a, M., \& Hamabadat, L. (2020). International Accounting Standards and International Financial Reporting (3rd ed.). Dar Wael Publishing, Amman, Jordan.

Al-Amoudi, Al-Khayyal, A., \& Tawfik. (2011). A study on the relationship between cash flows and earnings per share. King Abdulaziz University Journal of Economics and Administration, 135-181. Retrieved from http://platform.almanhal.com/Files/2/8326

Al-Khalayleh, M. (2018). Financial Analysis Using Financial Data (6th ed.). Wael Publishing, Amman, Jordan.

Alqam, M. (2018). Analysis of the financial statement for the purposes of decision-making and performance evaluation (1st ed.). Amman, Jordan.

Dergham, S. (2008). A study on the relationship between cash flows and earnings per share - 2008, An applied study on national banks operating in Palestine. Master Thesis, Islamic University, Gaza, Palestine. Retrieved from http://maherelayouti.hooxs.com/t71-topic\#top

Jamal, Dabash, Mahmoud, \& Amira. (2015). The Impact of Cash Flows on Financial Decision Making. Master Thesis, College of Graduate Studies, An-Najah University, Nablus, Palestine. Retrieved from http://safadn.blogspot.com/2019/03/blog-post_54.html

Matar, M. (2010). Recent trends in financial and credit analysis (3rd ed.). Wael Publishing, Amman, Jordan.

Robinson, T., \& Munter. (2004). Paul, Julia grant, financial statement. Pearson Education.

Shamaa, K. (2020). Analysis and evaluation of the performance of commercial and Islamic banks (1st ed.). Dar Wael Publishing, Amman, Jordan.

Subramanyam, K. R. Financial Statement Analysis. McGraw-Hill Education.

White, G., \& Sondhi, A. (2003). Ffried, the analysis use of financial statement (3rd ed.). John wily \& Sons Inc. 